\title{
Mixed-Marriages in the Liturgical Catholic Church Tradition
}

\author{
Gianandrea Di Donna*
}

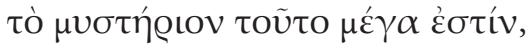

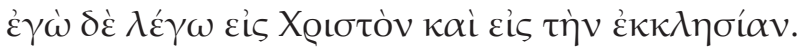

(Eph. 5.32)

The question of inter-confessional marriages concerns all the Churches and has become much more urgent because of the great mobility of contemporary man. The Christian wedding is seen as a sacrament of Christ by the Orthodox Church and the Catholic Church, while the Churches born from the Protestant Reformation do not take this sacramental view, although Luther considers the divine blessing on the institution useful. The advantage of a sacramental perspective lies in the fact that the spouses, by virtue of the sacrament of marriage, become capable of "being married" according to the quality of Christ's paschal love for his Church. In this way, according to the author, other theological perspectives open up, for example the sequela Christi, the idea of the vocation to Christian marriage, the foundation of the bond of indissolubility-fidelity and the foundation of sexual union-fruitfulness.

Keywords: Mystery, coronation, blessing, consent, Christ the Bridegroom, Bride Church, Churches, Cross, Liturgy.

The holy Mystery of the Christian wedding is seen by the Orthodox Church and the Catholic Church as a sacrament of Christ, while the Churches born of the Protestant Reformation do not view this sacramental perspective in the same way, while at the same time recognizing that the reality of the union of man and woman is inscribed in Creation and in Christian Revelation, according to the plan of God.

The Orthodox Church has a perspective of Christian marriage very close to Scripture and ancient Jewish tradition: the rite is usually divided into two parts (in the Byzantine tradition, but also in other traditions) which for convenience we could call: a. sponsalia with the exchange of rings (sometimes the Eastern Churches call this part engagement); b. and then the coronation itself, the nuptialia (which sometimes is called marriage). In reality, the two parts of the rite rather than an engagement followed by the actual marriage, probably bear witness to two different historical phases of the relationship

\footnotetext{
* Rev. Prof. Gianandrea Di Donna, Theological Faculty of Triveneto, Italy. Address: Via del Seminario, 29, I-35122 Padova, e-mail:gianandreadidonna@gmail.com
} 
between "civil" and "religious" weddings. These two pillars of the Eastern marriage ritual are very similar to the ancient Jewish tradition of marriage, also divided into: 1. the qidduschin (sanctification) also called erusin (achievable with a dowry - kesef - or with a written document - shetar - or with cohabitation - biah-) and 2. the nissu'in (the fulfillment of the wedding) with the rite of huppah.

The dogmatic perspective of the Orthodox tradition on marriage is closely connected to the general Eastern perspective on the sacraments: they are $\mu v \sigma \tau \eta \dot{\rho} \alpha \alpha$, we could say the design with which God makes man participate in His divine life. As through the Incarnation of the Word, man has been deified, without ceasing to be a man, so in the sacraments earthly matter receives the glory of God, without ceasing to be matter. Christian marriage is, for the Orthodox Church, a reflection of the image of the marriage between the Incarnate Word, Bridegroom of deified humanity, and the Church, Bride of the Holy Lamb. In the marriage between a man and a woman we see the image of Christ's spousal relationship with the Church, to which $\mathrm{He}$ has permanently united himself with His Cross, the "nuptial bed" (thalamus) of divine Love for sinful humanity (cf. Eph. 5). In this sense there is no other icon of the Mystery of the marriage between Christ the Bridegroom and the Bride Church than the union between the male and the female; a unique and unrepeatable union that excludes all polygamy but also any new union after the death of the spouse, after widowhood, referring to the image of the eternal love of Christ and the Church. The orthodox discipline which, by ecclesial economy, grants a second marriage to widowers and the possibility of a new marriage to the divorced, indicates an exception to the law that favors marriage to fornication (the Pauline principle of it is better to marry than to burn with passion, 1 Cor. 7.8-9).

The perspective of the Protestant Church born from Luther's reflection on the sacraments and that of the successive Reformers arises from a different point of view: in fact marriage, although belonging to God's plan of creation, was not instituted by Christ as a necessary sign for the grace of salvation, nor did Christ ever bind a promise to marriage; for Luther the Catholic Church attributes a sacramental value to marriage and sees this founda-

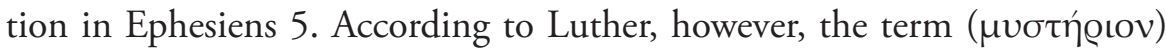
sacramentum (Eph. 5.32) describes only the relationship between Christ and the Church but not the relationship between man and woman. It remains true that God's command to grow and multiply (Gen. 1.28) cannot be disregarded: it urges Christians to sanctify themselves through this path of obedience to the Creator. Even in Luther's theology, marriage cannot be traced 
back to the simple pact-contract between man and woman, but to means of sanctification by which to redirect sexual disorder towards a more authentic and fruitful love: children receive physical, spiritual and religious life. This leads Luther to consider the divine blessing on the institution useful; so we can say that Luther still needs a wedding liturgy which was very close to the Catholic one at the time. Very similar are the positions of Calvin who exalts the union of man and woman as the divine image of una caro.

Introducing the perspective of the Catholic Church, I would like to say that the question of inter-confessional marriages can only be analyzed according to a dogmatic perspective or a perspective that unites the dogmatic one with the liturgical one. This is not because the liturgy should not be a coherent expression of the faith of a Church, but because we believe that the celebration of faith (the liturgy) enlightens the truths of that faith, according to the ancient adage lex orandi statuat lex credendi: we would like to say that liturgy strongly contributes to the understanding of the faith proper to a Church.

The question of inter-confessional marriages concerns, in fact, all the Churches and has become much more urgent for the reason, known to all, of the great spatial and cultural "mobility" of contemporary man. The very definition "inter-confessional marriages" restricts, as is understandable, the question only to marriages between baptized persons belonging to the different Churches: Catholic, Orthodox and Reformed. From a theological perspective (especially from the Orthodox Church) this consideration of marriage as a sacrament between baptized persons is absolutely coherent. The challenge that comes from contemporary society also widens the prospect of the possibility of marriages between Christians (baptized) and non-Christian people or of no religion. The expression "mixed marriages" is in fact used by the Catholic Church - this must be clarified - also in this sense, meaning that referring to two very different cases:

a. Weddings that are celebrated between a man and a woman who are validly baptized the first in the Catholic Church and the other in the Orthodox Church, in an Eastern Ancient Church or in a Church born from the Reformation (of classical tradition or new tradition). The Catholic Church believes that these marriages are a sacrament of Christ, precisely because of the fact that a sacrament can only take place between baptized persons.

b. Marriages that are celebrated between a man and a woman of whom one is baptized in the Catholic Church and the other (man/woman) is a catechumen or a non-Christian, that is, he (she) belongs to another non-Christian religion, or is an atheist. The Catholic Church believes that even this kind of marriage is possible, even if it is to be celebrated only with the Bishop's dis- 
pensation. This case, lacking the Baptism of one of the two parts, is not considered a sacrament by the Catholic Church. Nevertheless, the pact (unique, indissoluble and fruitful) is considered a possibility - given to two people who love each other - to live together in such a way that: 1 . the Catholic (one) may nevertheless unite himself (herself) with the unbaptised person before Christ, we would say according to the logic of Christian love; 2 . the non-baptized person (the other one) instead (sharing and freely choosing to share the values of a unique, indissoluble and fruitful conjugal love) allows the loved person - and this for his (her) sake - to live the union of marriage with him (with her) according to the law of Christ. The non-sacramental dimension of this indissoluble pact does not prevent the Catholic from living a Christian union with a non-Christian spouse.

These two cases show us the challenge, in times of great globalization, to recognize how the Christians of Europe actually open their affective relations beyond what we could define as the "Christian borders". The current liturgical tradition of the Catholic Church opens, then, a new perspective that I wish to present.

We know well how at the beginning Christian Marriage did not foresee particular ritual forms: the cultural and popular customs of the time came to be the form of marriage contract that Christians used ${ }^{1}$, however, aware of the fact that their wedding was a "nubere in Domino"; so until the II-III century. Already from the fourth century the Christian wedding took on a more properly ritual structure: 1 . velatio nuptialis in Rome (also in Milan - Ambrosian Liturgical tradition) with a solemn formula of blessing; 2 . the deductio in domo mariti (of religious type) in Spain and Gaul.

c. The $\sigma \tau \varepsilon \varphi \alpha ́ v \omega \mu \alpha$ in the East; already in this age there is a certain relationship between Marriage and the Eucharist. From the Carolingian period onwards, marriage is celebrated in facie Ecclesiae with great public character, also to protect women from the abuses to which they were sub-

1 For the vision of marriage in the ancient world see: Mario Righetti, Manuale di storia liturgica. IV. I Sacramenti - I Sacramentali, Milano, Ancora 1959 (anast. 1998), p. 453-455; Adrien Nocent, "Matrimonio. B: In Roma e nell'Occidente non romano", in: Anscar J. Chupungco (ed.), Scientia Liturgica. Manuale di Liturgia. IV: Sacramenti and Sacramentali, Casale Monferrato, Pontificio Instituto Liturgico Sant' Anselmo 1998, p. 286-288; Jean Comby, "Il mondo greco romano", in: J. Comby et al. (eds.), Il mondo dove visse Gesù. 2. La civiltà greco-romana e la civiltà giudaica, Claustrum 25/2, Bologna, Edizioni Studio Domenicano 2005, p. 51-67; Jean-Pierre Lemonon, "Il mondo giudaico", in: Ibidem, p. 67-88.

2 This obviously led to the moral demands that faith introduced and the consciousness of indissolubility. Furthermore, as can be deduced from Pierre Jounel, "La liturgie de mariage. Etapes de son èlaboration", in: La Maison-Dieu 50 (1957), p. 31 ss., if the Church has avoided creating a proper ritual apparatus, nevertheless Christians were called to abandon superstitious, idolatrous or lascivious practices (such as deductio in domum mariti). 


\section{Gianandrea Di Donna}

ject; the Rituale Romanum of the Council of Trent of 1614 provides for the consent before the sacred minister, the blessing and delivery of the ring and finally the possibility of celebrating, at the end of the Rite of Matrimony, a Missa [Divina Liturgia] pro sponsis, within which, after the Pater noster, the venerable and ancient prayer of blessing of the spouses was placed". "After the II Vatican Council, the Roman Ritual of 1975 and even more in 2004, they chose to base the marriage ceremony on a very strong and close rapport between Marriage itself and the Eucharist. It is not only about "taking communion after Marriage" (and asking the necessary graces of God) but also about showing how we receive the Easter of Christ passion, death and resurrection in the holy mystery of the Eucharist, which is full revelation of the love between God and his people, as described in the biblical (and patristic) image ${ }^{4}$ of the marriage between Christ and the Church, consumed by the divine spouse on the thalamus of the Cross. This spousal relationship between Christ and the Church shows us the true relationship between man and woman, transfigured by the sacramental order: this is the Pauline vision of the great mystery of love: "This is a great mystery, but I speak in reference to Christ and the Church" (cf. Eph. 5.32). The mystical marriage between Christ and the Church is not only an analogy but it becomes a gift of grace made to the spouses. They, by virtue of the marriage sacrament, become capable of "being married" according to the quality of the love of Christ for his Church. From this vision of nuptial love as an epiphany of Paschal love between Christ and the Church, some other theological perspectives are opened up, for example the sequela Christi, the idea of vocation to Christian Marriage, the foundation of the bond of indissolubility-fidelity and the foundation of sexual union-fruitfulness. This Rite of Marriage in the Eucharistic celebration is strongly proposed by the Catholic Church for her children and does not exclude a priori that this liturgy can also be used in the case of a marriage between a Catholic with a son (or daughter) of another Christian Church that recognizes the sacramentality of the Eucharist, like the Orthodox Church.

The Catholic Church proposes, however, a second form: the Rite of Marriage in the celebration of the Word of God, the latter according a twofold

\footnotetext{
3 It belongs to the Sacramentario Veronense, 1110, of the VI-VII century.

4 Hosea: meaning of absence; Isaiah (45.14-21; 50.1; 54.1-10; 62.4-5): the disappointment of the bridegroom; Jeremiah $(2.1-7 ; 3 ; 31.22 ; 51.5)$ : the nostalgia of faithful love; second and third Isaiah: the return of the bride and the joy of the groom; Ezekiel 16.23; Synoptic Gospels (Mt. 22.2-3; 25.1-2): joy for the presence of the groom, the banquet for the wedding of the child, the expectation of the groom; John (3.28-29): joy at the voice of the bridegroom, the wedding of Cana, the search for and the meeting of the bridegroom; Paul: I have promised you to one husband, this mystery is great (Eph. 5.25-33); Apocalypse (21.2; 29.7): the bride of the Lamb, the guests at the wedding of the Lamb, the vision of the bride descending from heaven.
} 
possibility: the first with Christians baptized in the non-catholic Churches, the second between a Catholic and a catechumen or unbaptized. This liturgical model is influenced by important pastoral motivations (later expressed also with some ritual accentuations): on the one hand there is a strong awareness that the sacraments (the Marriage) presupposes faith ${ }^{5}$ (sacramenta fidei); on the other hand we see how - especially among the new generations - for a growing number of couples of future spouses, Christ, faith and the Church are not at the center of their lives but are placed only on its horizon. More and more baptized, oriented towards Christian marriage, are secularized and their intentions are far from the design of Christ. The 2004 Ritual presents, for the Italian (we should say European) context, the "case of couples who, despite not having developed a clear Christian orientation and not living a full membership of the Church, desire the religious celebration of marriage being baptized and not explicitly rejecting faith" 6 . This new ritual form could encourage new ways of celebrating marriages between Catholics and Orthodox and between Catholics and Protestants, in order not to have to deal with the issue of a Eucharistic communion between members of separated Churches.

This celebration elevates a ritualized traditio Sacree Scripturce (Delivery of the Sacred Scriptures) to new symbolic heights ${ }^{7}$ instead of the Eucharistic communion: this consignment should not be understood as a kind of "gift", but as a viaticum in the journey for their new state of life together and as a symbol of their search-for, and listening-to God; the intent of the rite is to generate the beginning of a new relationship with the Word of God that accompanies, challenges and converts man.

We then describe here the three ritual models of the Catholic Church: one based on the Eucharist and two on the Celebration of the Word of God.

\footnotetext{
II Vatican Council, Constitution on the Sacred Liturgy, Sacrosanctum Concilium, n. 59.

${ }^{6}$ Praenotanda 7, Rite of Marriage (Italian translation) 2004, p. 12.

7 Rite of Marriage at No. 142 provides for: Delivery of the Bible. If Holy Communion has not been distributed [this would be distributed only in the case of a Marriage celebrated by a deacon, in the absence of a priest, and for this necessarily with the ritual model "in the celebration of the Word" also for couples who have a good faith situation; it is not that a contradiction to the pastoral reasons cause in some cases a "celebration of the Word", above editor's note] and the priest (or deacon) deems it appropriate, the Bible is handed to the newlyweds. The priest (or deacon) placesthe volume of the Bible in the hands of spouses saying: "Receive the word of God. Let it resound in your home, warm your heart, be light to your steps. May your strength guard your love in fidelity and accompany you on your journey to meet the Lord". It remains true that this celebratory modality could have had a wider and more explicit breadth.
} 


\section{The Rite of Marriage in the Eucharistic celebration}

\section{1. introductory rites}

a. Start at the door of the church (with all relatives and friends) followed by a solemn entrance to the altar.

b. A memory of the Baptism, celebrated possibly near the baptismal font, reached with a procession and with the sprinkling ritual.

c. After the song of Gloria, follows the Opening Prayer ${ }^{8}$ which closes the rites of introduction.

\subsection{The Liturgy of the Word}

a. The new Lectionary offers a choice of eighty-two possible biblical readings.

b. At the end of the proclamation of the Gospel, the couple (spouses) venerate the Gospel Book, the presence of the Risen Christ who speaks to the Church; they venerate the Book with the kiss (osculum). This ritual gesture is an act of faith in the real presence of Christ' ${ }^{9}$ after obedient listening to the Word of God follows the commitment to live their faith in the presence and under the light of the Gospel.

\subsection{Liturgy of Marriage}

a. The Questions before consent or the new form of the Declaration, dictated by a single voice from the spouses.

b. The Consent follows, combined with the ancient gesture of the dextrarum iunctio, addressing each other. Closes the formula of acceptance of consent (note the rich biblical language of the "second formula" 10 ), with the ancient gesture by the presbyter to spread his hand on the joined hands of the spouses ${ }^{11}$.

\footnotetext{
8 The new ritual foresees six prayers (p. 243-244) of which the first four rework and replace the four of the Rite of Marriage (p. 737) and two are added from the ancient Roman tradition Ve 1109 and Gel 1450 (Roman Missal, 2004, p. 244), currently not present in the Roman Missal of 1983 (p. 737).

9 The influence of Sacrosanctum Concilium 7 which recites this, referring to the presence of Christ in the Liturgy, and especially in the proclamation of the Word of God, is felt strongly: "[Christus] presens adest in verbo suo, siquidem ipse loquitur dum sacrae Scripturae in Ecclesia leguntur".

10 The formula of acceptance of consent in Rite of Marriage 2004, n. 75, p. 45 evoking numerous biblical expressions (Exod. 3.6; Gen. 2.22-24; Mt. 19.6) regarding the alliance (spousal!) between Yahweh and Israel states: "The God of Abraham, the God of Isaac, the God of Jacob, the God who in heaven has united Adam and Eve confirm in Christ the consensus that you have manifested before the Church and sustain you with his blessing. Man does not dare to separate what God unites".

11 Gesture of the ancient sponsalia, which in the Germanic area will be expressed with the gesture of wrapping the hands of the spouses in the presbyter's stole, with the formula: Ego coniungo vos in matrimonium in nomine Patris [...].
} 


\section{c. The blessing and exchange of rings.}

d. The Rite (optional) of the Coronation of the spouses ${ }^{12}$. The biblical tradition gives prominence to the crown: both in the royal and cultural and symbolic senses, as well as in the nuptial ${ }^{13}$. This ritual, present in the Egyptian, Greek and Roman tradition ${ }^{14}$, merged into the Christian rite and had great fortune in the Eastern Byz-

12 Rite of Marriage 2004, No. 78, p. 47. The text that accompanies the rite is very simple - perhaps drawing on the Eastern tradition could have endowed it with greater eucological wealth - and is inspired by the current Byzantine formula: "N., servant of God, receive N., servant of God as crown". "O Lord our God, crowned with glory and honor". The possibility of coronation was desired in the manuscript 1975, at No. 17, p. 17.

13 There are numerous passages in which the crown appears with different meanings: $a$. crown as a diadem (Gdt. 15.13; Gb. 19.9; Ps. 89.40; Prov. 12.4; 14.24; Sir. 1.16, 6.31; 25.6; 32.2; 50.12; Isa. 62.3; Fil. 4.1 [“... my beloved brothers, my joy and my crown"] 2 Tim. 2.5); b. as a crown of gold (Est. 8.15, 1 Mac. 1.22; 10.20; 11.35; 13.37; 2 Mac. 14.4; Sal. 21.4 [“... put a crown of gold upon his head"]; Sir. 45.12; Jer. 13.18; Bar. 6.8; Ezek. 16.12 [Yahweh's bride Israel: "I put a ring on your nose, earrings in your ears and a beautiful crown on your head]; Zech. 6.11; Rev. 4.4,10 [are the old men with "... a crown of gold on their heads"], Rev. 9.7, Rev. 14.14 [Christ has "... On his head a golden crown"); c. as a royal crown (2 Sam. 12.30; East. $1.11 ; 2.17$ ["... the king placed onthe head of Esther the royal crown"]; 6.8; 1 Mac. 11.3; Ct. 3.11; Sap. 5.16; Isa. 28.1; Lam. 5.16; Ezek. 21.31; Mt. 27.29 [crown of thorns], $d$. as crown of glory: Gdt. 3.7, Ps. 132.18; Prov. 1.9 [the teachings are a "... graceful crown on your head"] Sap. 4.2; 18.24; Isa. 28.5 [“... The Lord will be a crown of glory”]; Ezek. 23.42; 1 Thess. 2.19 [“... You are the crown we can boast of"]; 2 Tim. 4.8; Gc. 1.12 [“... will receive the crown of life"]; 1 Pet. 5.4 ["... And when the shepherd will appear supreme receive the crown of glory that does not wither"], Rev. 2.10; 3.11; 6.2; 12.1 [the woman clothed with the sun "... with the moon beneath her feet and on her head a crown of twelve stars"]); God crowns men with his blessings (Ps. 8.6 ["... of glory and honor crowned him": the quotation which uses the Byzantine rite in the crowning of the spouses] and Heb. 2.7, even Jesus see him "... crowned with glory and honor" (Heb. 2.9), the image of the athlete Christi is known running to win the prize (crown) in 1 Cor. 9.4-27.

14 Pietro Sorci, "The veiling and coronation”, in: Rivista Liturgica 6 (2004), p. 1055-1056, as in Egypt were crowned the pharaohs and the gods, while in Rome and Greece the crown was a sign of consecration to the gods: "... In the sacrifice, sacrificer and victim are crowned. The statues of the gods are usually crowned with leaves of the trees and the fruits of their consecrated plants: the oak to Zeus, the laurel to Apollo, the myrtle to Aphrodite, the vine to Dionysius, the ears to Ceres". Moreover the coronation accompanied the cult of the dead or the initiation rites of the mystery cults; often the golden crown or the halo express an "identification" with the divine. In Christianity the crowns are a sign of dignity, power, royalty, holiness, gift from above, perfection (circle), eternity, aureola sancta; like kings and prophets, like those who obtain wisdom, like Mary, Queen of heaven and earth, but above all like Christ, crowned Rex Judeorum on the royal throne of the Cross. Even the crowning of the spouses is the sign of their participation in the kingship of Christ - already given with the Baptism -; they are the new Adam and the new Eve, who from now on have reached the "crowning-completion" of existence one in the other; one became "cause-reason" of salvation (= corona æternitatis) of the other, as if one had been dedicated to one another. The ritual recommends using gold or silver metallic crowns and decorated with sobriety; or flower crowns. 


\section{Gianandrea Di Donna}

\section{antine liturgies ${ }^{15}$, "Coptic ${ }^{16}$, Syriac $^{17}$ - who maintain a feast of the "Bride Church" -, Assyrian ${ }^{18}$ and Chaldean, Armenian" ${ }^{19}$.}

15 The Byzantine rite does not know an exchange of consensus, even if in some churches (Russians and Ukrainians) it has been introduced (by Western influence?); the rite leads into the medieval Eucologion (already present in the Eucologion Barberini of the eighth

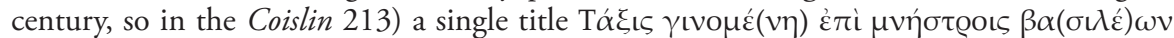
$\kappa \alpha i$ 入oı $\pi \tilde{\omega} v$. According to Miguel Arranz, I sacramenti dell'Ordine e del Matrimonio nella tradizione bizantina. Uno studio delle fonti liturgiche, Roma, Pontificio Instituto Orientale 1998, p. 42-51, the rite is divided into two parts: the first - a real commitment, "popularly" and mistakenly intended as engagement - it consists of diaconal litany, two prayers,

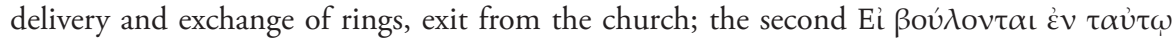

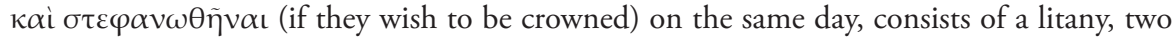
prayers, the coronation, the union of the hands, the prayer of the Pater, communion with the Presanctified and finally the common cup of wine drunk and crushed. The two sections probably bear witness to two historical phases of the relationship between "civil" and "religious" marriages. Interesting in this regard the Pontifical Oriental Institute thesis of Anne Schwerdtfeger, Ethnological Sources of Christian Marriage Ceremony, Stockholm, Ceres 1982. A third rite regards the "dissolution of the crowns". A single prayer, on the weakness of human nature, without canonical specifications or rubrics, constitutes the fourth rite called of

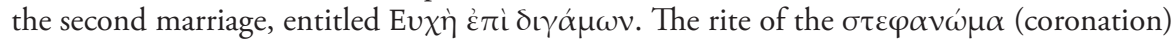
consists of a prayer before the imposition of the crowns ( $\mathrm{\Theta}$ cò ó ó $\alpha \gamma$ lo I sacramenti dell'Ordine, p. 47) so the addressing formula during the imposition of crowns

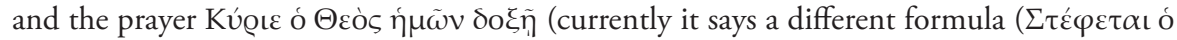

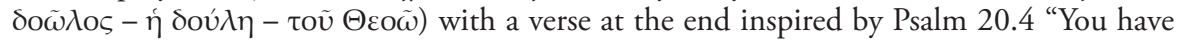
placed on their head a crown of precious stones...", see: M. Arranz, I sacramenti dell'Ordine, p. 47. Interesting prayer for the melting of the small crowns, the eighth day after the wed-

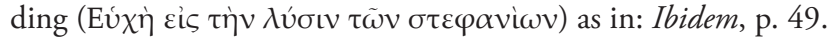

16 The very long Coptic rite of the coronation (Heinrich Denziger, Ritus Orientalium coptorum, syrorum et armenorum in administrandis sacramentis, vol. II, Wirceburgi, Typis et Sumptibus Strahelianis 1864 , p. 370-381) provides for the biblical readings, a litany, three orations follow, then the inclination of the head, the prayer over the oil, anointing of the groom accompanied by two prayers, the anointing of the bride, the prayer over the crowns (Domine sancte, here you crowned sanctos tuos coronis immarcescibilibus) and coronation, other prayers; the deposition of the crowns in die septimo closes .

17 The Jacobite Syrians have their own Officium secundum quod est ad benedictionem corone nuptialis (H. Denziger, Ritus Orientalium, p. 391-402, another Syriac ordo at p. 408-418) with prayers, long responsories, prayer of incense, the presbyteral oration before the coronation turned to the east (Deus qui ordinasti in firmamento coronam preclaram), the prayer to the imposition of the crown manibus deacons (Deus abscondite); then the verse at the crown's position; two super orations sponsum, two super sponsams and one super utrumque; a super patrinum and a super matrinam; other final prayers.

18 The Nestorian Assyrians have an Ordo coronationis (H. Denziger, Ritus Orientalium, p. 433-446) composed of a coronation at the beginning, during the second canticle, followed by various, numerous and long orations, which close with a Glorificatio and a Proclamation followed by the blessing of the bridegroom with the imposition of the right hand followed by a blessing super sponsam and two pro paranymphos and pro paranympha; a consignatio closes.

19 The Armenians (H. Denziger, Ritus Orientalium, p. 463-464) have a simple coronation ritual of the bride at the end of the Eucharist: the groom sits, the hymn is said Orbis terrarum and other prayers, the hymn Omnipotens Domine rex, then the spouses return home; 
e. Then follows the solemn nuptial blessing (RM 2004, No. 79, p. 47): today, compared to the ancient location after the Pater nos$t e r^{20}$, it is close to the consent showing the pneumatological dimension of the ritual: a nuptial epiclesis which more clearly shows the mutual consecration of the spouses. Thus appears the teandric character (i.e. the dimension divine-human) of the sacrament of Matrimony. In fact the Marriage has a human, natural dimension, based on freedom, a "horizontal" dimension that we see represented by consent ${ }^{21}$. This first dimension intersects with a second that we would call vertical, divine, spiritual, gratuitous, "comingfrom God"22 and from his gift: it expresses, once again, those mystical weddings between Christ the Bridegroom and the Bride Church, united by a divine love that transfigures, through his action, the human love of Christian spouses, making them a sign of Christ's paschal love for the Church. This solemn blessing has been enriched by some ritual indications: the gesture of kneeling by the spouses; the epicletic gesture of the presbyter to stretch out his hands on the spouses; the song of blessing by the presbyter (RM 2004, p. 261-264). This proximity of the solemn ritual blessing to the consent overcomes, by liturgical route, the opposition between the Church of the East and the Church of the West, and proposes a balanced "ministerial symphony" 23 between

the priest returns to remove the crown: he places the couple in a place, "head against head", and pronounces the blessing with the sword saying the hymn Hodie martyrum, three lectiones (Hos. 14.6-8; Ero quasi ros vinum Libani; 1 Tim. 2.9-15; Hallelujah; Jn. 2.1-11) other prayers. The Armenian Catholics (H. Denziger, Ritus Orientalium, p. 472-475) provide for an Ordo benedicendi virginis coronam: enter through the door of the church, Pacem largire is said, then some prayers, 7 lectiones (Gen. 1.26-28; 2.18; 2.21-24; Prov. 4.20-5.14; Isa. 61.962.6; Eph. 5.22-33; Mt. 19.1-9); then the Creed, a litany; they place the crown before the bema, the prayer Domine Deus exercituum, other prayers, then place the crown on the head of the bridegroom and of the bride saying the prayer In nomine tuo vivo; thus the Eucharist is celebrated; atthe end, the newlyweds return home. Then there is an Ordo tollendi coronam (H. Denziger, Ritus Orientalium, p. 476-477), with some litanies and prayers.

20 Historically, the position of the super-sponsorship blessing has had fluctuating locations and in the early Middle Ages it found a place between the Pater and the Libera nos. The motivation - still valid - is based on the link "Matrimony-Eucharist".

21 This "horizontality" is manifested through the mutual consent of the nubendi, which, both for Roman law and for the Roman Catholic Church, has always been considered the fundamental element and the discriminating criterion for judging the validity of marriages, according to the ancient adage consensus facit nuptias.

22 It is precisely manifested by the bridal Blessing, the type of invocation-epicletic.

23 Andrea Grillo, "Il matrimonio e la salvezza dell'altro. Per una teologia liturgica del rito secondo l'edizione italiana", in: Rivista Liturgica 91 (2004), p. 1028-1029: "No one ignores 
the ministry of the spouses (given by their free consent) and the ministry of the presbyter (the ecclesial ministry and the ministry of invocation).

f. It is finally possible to accompany the solemn blessing with the rite of the imposition of the veil of the spouses or veiling (RM 2004, No. 84 - rubric on p. 52). It wants to express on the spouses the communion of life that the Spirit, enveloping them with his shadow, gives them to live. During the imposition, the veil will be held up by the parents or by the witnesses over the head of the spouses, for the duration of the whole nuptial blessing. The veil is white with the possibility of an appropriate, sober ornament. This gesture, full of suggestion, comes from the Jewish tradition of huppah, the canopy built at the synagogue or in the groom's house, under which the wedding was celebrated ${ }^{24}$.

the fact that consensus and blessing indicate not only two centers of the sacrament (of which the Western tradition and the Eastern tradition have valued equally) but also two different visions of the ministry proper to this sacrament. This connection also speaks of the overcoming of an antithetical ecclesial vision, which can finally experience the truth of the lay communion only in relation to an undeveloped ecclesial ministry, but which recognizes the truth of the hierarchy only in witness service to a possible and real communion of lay baptized".

24 With the term huppah (see the excursus on huppah in: Pietro Dacquino, Storia del matrimonio cristiano alla luce della Bibbia, Torino, Leumann 1984, p. 25-26) one designates the thalamus which, however, does not indicate precisely the bridal chamber (difficult to imagine in antiquity, when there was only one room in which everyone slept): the verb $h p h$ that indicates the "cover" seems to refer to a temporary construction for spouses to be able to separate at the beginning of cohabitation. In medieval times, the spouses, after the celebration in the synagogue, went out and entered a building ( (uppah), made of four poles and a veil spread over it (It will turn into a canopy or a simple tallit, veil of prayer), under which the groom handed the ring and then the bride's father recited seven blessings; then they drank from a cup that was then broken. The veil as such has an ancient history of meanings [See for the meaning of the veil, the same voice in: Manfred Lurker, Dizionario delle immagini e dei simboli biblici, Milano, Cinisello Balsamo 1990, p. 227-228]: it hides the face and rejects bad influences (the spirit of the dead, the libidinous demons); the vestals brought it to Rome so that they may be considered caste spouses of divinity; Roman brides wore the flammeuum, a red veil; the veil was spread during the spousal ritual of the confarreatio: probably from this ritual of the veil-cover derive the Latin verbs and nouns nubere (whose etymology is precisely

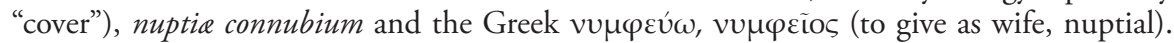
Sometimes the veil represents the starry sky behind which the divinity is hidden. In liturgical biblical symbolism it recalls the tent, the dwelling of God on earth, the luminous cloud of the presence of God, the heaven that God spreads to embrace and protect the earth (Isa. 40.22); the veil covers the face of Moses when he is blinded by the glaring light of the bush and covers his face (Exod. 3.6), Moses covers himself with the veil even after the encounter with God on the Sinai (Exod. 34.33,35); he calls the tent of the covenant on which the luminous cloud that fills it is spread (Exod. 40.34-38; Num. 9.18-22; 10.34); a veil in the temple marked the sancta sanctorum; in the New Testament is the Holy Spirit descending on Mary (Lk. 1.35); the Spirit that descends on Jesus to the Jordan (Mt. 3.16; Mk. 1.10; Lk. 33.22; Jn. 1.32); the cloud to the Transfiguration (Mt. 17.5), the ciborium on the altar, permanent 
g. The usual prayer of the faithful with an invocation (litany) of the saints, is the memory and intercession of those who lived holily and faithfully in Matrimony (RM 2004, No. 81, pp. 48-50), an eschatological sign and of the intercession of the heavenly Church. When it is prescribed, the profession of faith is made.

\subsection{The liturgy of the Eucharist}

a. The spouses can bring to the altar the holy gifts of bread and wine, a sign of the Marriage-Eucharist relationship, with the invitation to collect offers for "particular situations of poverty".

b. The mention of the spouses is made into the Eucharistic Prayer.

c. The Rite of marriage has its symbolic and theological summit in the holy Communion of the spouses sub utraque specie.

\subsection{Concluding rite}

a. The blessing, the canonical provisions and the signature of the Marriage Act.

b. The dismissal.

\section{The Rite of Marriage in the celebration of the Word of God}

The second form called the Rite of Marriage in the celebration of the Word of God expected for the cases we have mentioned above: the latter according a twofold possibility: the first with Christians baptized in the non-catholic Churches, the second between a Catholic and a catechumen or unbaptized.

\subsection{Introductory rites}

a. Similar to the first scheme, provide for the memory of Baptism.

b. A prayer closes this opening rite.

\subsection{The Liturgy of the Word}

a. With the same principles of the first scheme, it is inaugurated with an introductory monologue.

b. It also closes with the kiss of veneration of the Gospel by the spouses.

\subsection{Liturgy of Marriage}

a. The Questions.

b. The Consent.

epiclesis on the oblates; synthetically it is memory of the nimbus-cloud protection of God and of the epiclesis of the Holy Spirit-Love on the "lovers". 
c. The Blessing and exchange of rings.

d. The Wedding blessing.

e. Prayer of the faithful and prayer of the Lord.

$\mathrm{f}$. The introduction of the Ritual of the delivery of the Bible, understood not as a gift but as a viaticum fidei on the path of renewed Christian initiation of the spouses. The celebration of their Marriage, centered on listening to the Word of God, has - in the entrusting of the Word itself - its ritual culmination: the Word of God becomes the greatest gift received, in view of this commitment to continue the itinerary of faith.

\subsection{Concluding rite}

a. Blessing

b. Agreements and the signature of the Marriage Act.

\section{Rite of Marriage between a Catholic part and a catechumen or non-Christian part}

The third scheme provides the form in the celebration of the Word of God, for Marriage between a Catholic and the other catechumen or non-Christian; the scheme adopts - with intelligent variations such as the omission of references to the grace of Christ or the name of the Holy Trinity, or the reserve of the Lord's prayer to the Christians present only - texts and symbology from the second rite (Marriage in the celebration of the Word of God):

\subsection{Rite of welcome:}

a. Welcome of the spouses at the church door.

b. Opening Monition. It is good to provide a text that expresses the situation of the nubendi, with respect to the faith of one side and the other (if it is a catechumen) or its religious dimension (if belonging to other religions or any religion). It will be appropriate to underline the values that the two have in common.

\subsection{Liturgy of the Word}

\subsection{Celebration of Marriage}

a. Questions: the role of these questions as a manifestation of the "natural" gifts that the Marriage bears in itself can also be shared with those who have another religion or do not believe.

b. The Declaration of consent follows, accompanied by the gesture of dexterarum junctio and from the acceptance of consent. 
c. Depending on the circumstances, the blessing and exchange of the rings may take place, but it is also possible to omit this ritual. If you do, the mention of the Holy Trinity in the exchange of the rings themselves, can be added only if the one who says it is Christian.

d. The nuptial blessing is foreseen, but if circumstances suggest it one can imagine, for example, that the different religious faith makes such a choice inappropriate - it can be substituted by a short prayer. It ends with an acclamation.

e. A short prayer of the faithful closes with the prayer of the Lord, to be pronounced - as the rubric recites - only by the Christians present.

\subsection{Conclusion of the celebration}

a. A super populum blessing is pronounced.

b. Then follows the concordat provisions and the signature of the Marriage Act.

\section{A brief final perspective}

The Catholic, Orthodox and Reformed Churches' visions of the Christian wedding show different theological and ecclesial emphases. However, these have their own common ground starting from the fact that, in the practice of each Church, marriage happens in the context of an action of grace. Now, since the three Christian confessions share the same Baptism in water with the invocation of the Most Holy Trinity, it would seem possible that the common ground for inter-confessional marriages is precisely the rite. Inspired by the model of the Rite of marriage in the celebration of the Word of God, the wedding liturgy (without the celebration of the Eucharist) could be conceived in the ecumenical sense as an expression of God's work of grace. Rituals could be structured in this way: a. listening to the Word of God (of Protestant inspiration), b. the consensus (of Catholic inspiration), and close with the crowning of the spouses (of Orthodox inspiration).

The dream would be to be able to set up a liturgical commission, instructed by the Bishops of the three Churches, which would be in charge of preparing, and eventually getting approved (by the Churches themselves) a wedding celebration for inter-confessional marriages. Its ritual structure would be recognizable by all as an effective sign of the blessing of God when He unites a man and a woman in marriage through the work of His grace. 